\title{
JOHN BROWN AMONG THE PEDEE QUAKERS.
}

[Oontinued from page 670.]

\section{CHAPTER II.}

In the beginning of the winter of $1857-8$ Brown, for the fifth time, visited the Quaker settlement of Cedar County, determined, as now appears, to spend the winter there in preparation for his Harper's Ferry raid, the plan of which he now disclosed to some of his confidants at Pedee-Jas. Townsend, John H. Painter and Dr. H. C. Gill. On this occasion he was accompanied by his band, consisting of his son Owen, Aaron D. Stevens, John Kagi, John E. Cook, Richard Realf, Charles W. Moffitt, Luke J. Parsons, Charles H. Tidd, William Leeman and Richard Richardson, the latter a colored man, who, with his wife and three children, had made his escape from slavery in Missouri.

Stevens had been an enlisted man in the United States army, and being stationed at Fort Leavenworth, one day while drilling a squad of men at the Fort, got into an altercation with a commissioned officer, ${ }^{*}$ at whom he fired, and for which a court-martial condemned him to be shot; but he escaped, and joined his fortunes to those of Brown in Kansas. Kagi, Brown's favorite, was about thirty years old and a native of Virginia; he had a tolerable education, was a fluent speaker, and an excellent stenographer. Realf was a fair scholar, of fluent speech, and a ladies' man, having left one sweetheart in Kansas and won the heart of another at Springdale. He represented himself as having been an amanuensis to Lady Byron, the poet's widow, and confessed to having been obliged to leave England on account of his participation in the Chartist riots of London in 1848. During the Kansas war, he was a correspondent from that turbulent Territory for the New York Tribune. For some reason or other, he failed to come to time at Harper's Ferry. Tidd hailed from the western part of Lowa. Just after the Harper's Ferry fight, he made

* Said to have been Lieut. Longstreet, afterwards a general in the rebel army. 
his escape with Cook, and, more fortunate than the latter, succeeded in eluding his pursuers. He enlisted in the navy, during the war, under an assumed name, and died in the service, at Roanoke Island, of typhoid fever. Just before his death, he discovered to a comrade his real name and history. William Leeman was a youth from Massachusetts. He was slaughtered at Harper's Ferry, while begging for mercy. There is nothing sufficiently striking in the history of the others, except what is familiar to the public, to require recording here.

Besides those named above, who accompanied Brown from Kansas to Cedar County, he had accessions to his company in the persons of some of the young men resident in the Pedee Settlement. Among these were George B. Gill, the two Coppi brothers, and Stewart Taylor. Mr. Gill, who held a high position in Brown's confidence, having been the secretary of the treasury of his provisional government, was detached from the party in Canada, previous to the Harper's Ferry affair, after which he returned home and married; since which his issues have been more quoted and have borne a higher preminm than formerly. We never heard that he had any trouble in accounting for the contents of his portfolio. If the provisional government, of which he was a cabinet officer, ever issued bonds, they probably had the same value a like quantity of any other Brown paper had. Edwin Coppic was hung, as will be recollected, while his brother Barclay escaped and returned to his home in Springdale, where his mother still resides, to be the subject of a requisition by the Governor of Virginia on the Executive of Iowa, and a text for much controversy in the spitfire press. He finally fell a victim to the barbarous warfare of the Missouri bushwhackers, who partially burned the supports of a railroad bridge, and the next train attempting to pass thereover, and on which Coppic chanced to be, was precipitated many feet into the stream below, and a large number of Union soldiers, Barclay Coppic among the number, instantly killed. 
Brown quartered his men daring this winter at the house of Mr. William Maxson, three miles north-east of Springdale. There is an additional historic interest attaching to this house -it being the first cement or gravel house ever built in this State. The farm on which it stands was bought by Mr. Maxson at the first government land sale held in Dubuque in 1839, and the house, which is of cottage-style in architecture, 32 by 25 feet in the main part, was built in 1849 . Here Brown's men-were trained for the projected raid-assiduously drilling with wooden swords Brown himself had his quarters at the home of Mr. John H. Painter, about a mile distant, and the men were under the immediate command of Stevens, who was the drill-master. Considerable attention was paid to diseipline. Each hour of the twenty-four had its allotted duty. The men were required to rise in the morning at tive o'clock, and drill and study alternately occupied the hours of daylight. With the exception that Tuesday and Friday evenings were set apart for regular debates, which all were required to attend, their vesper hours were generally spent according to inclination. Singing, ehatting and flirting with the fair young Friends of the neiginborhood, a pastime which began at early candlelight, absorbed a good portion of the time of each of the party, but especially of Cook and Realf, who were considered by the simple-minded young Quaker ladies great critics in all that pertained to etiquette and polite manners. Maxson, the host, being an enthusiast in spiritual doctrine, as promulgated by the cunning Fox girls, soon converted most of his guests to a like belief, and when the weather forbid out-door enterprises, recourse was had to spirit-rapping. Besides these occupations, Realf gave occasional lectures in the neighboring villages, Cook visited the schools and made addresses to the scholars, while other less intellectual members of the party chopped wood, husked corn, and engaged in such other useful occupation as commended them to the settlers.

On Thursday, April 22, 1858, Brown, having returned from the east. (whither he had gone to arrange some prelimi- 
naries,) bid his men prepare for the grand movement. The parting from their friends, which took place on the 27th of April, is described as having been affecting in the extreme,not an eye was dry except the two that belonged to the imperturbable Brown, and in the confusion Cook kissed a very handsome young school teacher, Miss Blake, probably in mistake for one of the old grandams of the place. It must be recollected that they left with the full expectation of striking the blow immediately, which, however, was ordered to be postponed by a convention which shortly afterwards met at Chatham, Canada West, to which point they went directly from Pedee. This convention also framed a constitution and elected provisional officers.

Postponement having been decided upon, Brown again returned to Kansas, and on the evening of February 4th, 1859, we once more find him on his way to Pedee, crossing the Missouri river at Nebraska City, accompanied by a few of his party, together with twelve negroes-one of the latter but a few weeks old, and born while the party were at Dr. (now General) Blunt's. After crossing the river, they marched rapidly to Mount Tabor, stopping one night on the way at Dr. Blanchard's. After resting a week at Mount Tabor, they pushed for Des Moines, putting up at night successively at the houses of Mr. Tool, Mr. Mills, and Mr. Murray, the latter's place being a little east of Irishtown. On February 18th, they crossed the Des Moines and entered the present State capital. Mr. John Teesdale, then editor of the Register, paid their ferriage. Teesdale and Brown had been old personal friends in Ohio, but until now Teesdale was not aware that Ossawattomie Brown and his Brown were one and the same. On February 20th, they reached Grinnell, and became the temporary guests of the present representative of the Fourth District in Congress, who was at home then much more than on the 14th of June when Gen. Roussean paid his respects to him, and who delivered a discourse in the church at Grinnell to Brown and his party, besides many 
of the citizens of the town who were attracted by the novelty of the occasion, and contributed a generous sum to help them on their way.

On the 25th of February, Brown, with his party, for the last time, gained the hospital hamlets of Pedee, having passed through Iowa City the night previous.

It immediately became street talk in Iowa City that Brown, with a large party of fugitive slaves, was in the vicinity; and, as a reward of three thousand dollars had been offered by the authorities of Missouri for the arrest of the negroes, the disinterested advocates of the rigid enforcement of the fugitive slave law, who cared nothing particular about other laws, began to discuss the propriety of collecting a mob, marching on Pedee and capturing Brown and his party. Sam Workman, then Post Master at Iowa City, was the captain of the gang organized for this purpose, but Brown having returned a reply breathing quiet defiance to Workman's threat of capturing him, the Post Master, after consulting his friend Capt. Kelly, an Irish gentleman of great eminence, that is to say, six feet and seven inches tall, deferred the undertaking.

At this stage of the proceedings, Mr. Grinnell, fearing trouble, proceeded to Chicago to endeavor to secure a box car, in order that the negroes might be removed quietly. Mr. Tracy, the superintendent, refused to allow the negroes to pass over the railroad, being afraid of a prosecution under the fugitive slave law. Tracy, however, gave Grinnell his draft for fifty dollars, and this draft Grinnell handed to Brown on his return from Chicago. While this was going on the United States Marshal, Summers, was at Davenport, alleging that he had a warrant for the arrest of Brown and his party. At this juncture, W. Penn. Clarke, who had been absent, returned home, apprehending difficulty and even the loss of life, as he knew Brown would fight rather than be taken. Shortly after Clarke's return, Brown visited Iowa City, (as he frequently did while stopping at Pedee). Hear- 
ing of Cliarke's return, Brown sent to request Clarke to visit him at Dr. Bowen's, where he was to stay over night. Here Clarke learned of the effort Grinnell had made, and of its failure. After some discussion, Clarke undertook to obtain a close box car in which to run the negroes through to Chicago. Accordingly, Clarke set out by the early train next morning, and Brown was to be ready next day with his entire party, at West Liberty, a station on the railroad fifteen miles east of Iowa City, and ten miles south of Springdale. It was finally agreed that Clarke should send some one to pilot Brown out of the city, and that the latter should leave in the night, and avoid the main read till he got some distance from town. Accordingly, Col Clarke, in company with Major L. A. Duncan, (now the editor of the Niles, Michigan, Times, then of the Iowa City Republican,) knocked at the door of Col. S. C. Trowbridge, who had been selected for this delicate duty. It being by this time midnight, the Colonel was well into his first slumber, but immediately awoke, and hastily put himself in such light marching order as to go to the door. He readily promised to perform the duty assigned him, merely stipulating that he should do it in his own way. Therefore Trowbridge, by four o'clock, was at Dr. Bowen's, where Brown and Kagi slept. One of Sam Workman's men was keeping watch over Brown's horse in Bowen's stable. The early movements of Brown were probably not coutemplated in Workman's strategy, which undoubtedly was to take Brown in town that morning, and then make an easy conquest of his party, deprived of its head, at Pedee. That as it may, Brown and Trowbridge, each on his proper horse, and Kagi on foot, were soon floundering in the darkness and mud of the "upper Muscatine road," bound for Pedee, among whose quiet cottages Trowbridge parted for all time from the adventurers, in the morning gray.

The most difficult part of the plan was to procure the car from the railroad company, but this difficulty soon melted be- 
fore the commendable finesse of Clarke, who called on Hon. Hiram Price, then Secretary of the railroad company, to whom he confided his business. Price had no control over the cars, but gave (llarke a note of introduction to Mr. Moak, the Deputy Superintendent. With this note from Price, and Tracy's draft, which he had got from Brown, Clarke retraced his steps to West Liberty, where he found Brown waiting: his party being concealed in Keith's Steam Mill. As the train bound east would soon be along, despatch was all important. The agent, Miller, had just gone to dinner, about a quarter of a mile off. Enoch Lewis, an old man, volunteered to bring him. The agent was soon at the hotel, where by this time Clarke and Brown had made a junction. To obtain the car, it was necessary for Clarke to make the agent believe the railroad officers knew and connived at what was being done. So Clarke showed him the note from Price introducing him to Moak, and asked him if he knew the signature. Of course he recognized it as the sign manual of the Secretary of the road. In the same manner was exhibited to him the draft from Tracy, which he likewise knew to be in the handwriting of the Superintendent. Clarke then asked him if he had a close box car, and the cost of running it to Chicago. He answered that he had such a car, and that the price would be fifty dollars. Thereupon he was handed Tracy's check, and Clarke told him he wanted the car at once down at the mill, and that it was not his (Miller's) business to know what was going to be put into it. The car was accordingly run down the track in front of Keith's mill, and the fugitives, with the white men Brown had with him, were loaded in as freight-Stevens being at one end of the car and Kagi at the other. All of the men, both white and black, were heavily armed. Clarke, Brown and Kagi dined at the hotel together. During this repast, Clarke gave Brown ten dollars to help him on his way, and advised him to go home and take some rest, which he promised to do.

When the passenger train came along, Brown got into the 
car with the negroes. By this time it was noised abroad what was going on, and the whole town of West Liberty was out, all being in sympathy with Brown and his fugitives. Clarke's freight car soon formed a link in the chain of coaches. Clarke and Kagi got into the passenger car to be prepared for emergencies, and with a shout of approval and sympathy from the people of West Liberty, off the train started for Davenport.

Brown and his party arived without molestation at Chicago, where they changed cars, taking another branch of the underground railroad for Canada, where they all arrived in due time. Tracy, the Superintendent, swore some, when the negroes were unloaded at the Chicago depot. A short time after, Clarke apologized to Mr. Farnum, the President of the road, for the harmless imposition he had practised on the agent at West Liberty, so that he did not lose his place.

[Concluded in next Number.]

\section{IOWA COLONELS AND REGIMENTS.}

The war has not given rise to a more entertaining volume than the one with the above title, written by Capt. A. A. Stuart, of Ottumwa, who was a co-laborer with those whose biographies he sketches, and an actor in the stirring events he relates, and therefore brought to his task from the start a personal acquaintance with the general subject he was to handle, of valne beyond our power to estimate in the preparation of such a work. His warm words of approval indicate a generous leaning toward praise, while an occasional sharp sentence of rebuke, shows that he does not always recoil from the duty of passing merited censure. It is written in such a lively and agreeable style as would impart a charm to even a tiresome theme, and is liberally interspersed with admirably engraved and attractive steel portraits, by Buttre, of the colonels whose biographies are given. Its mechanical execution, which must be credited to the printers and book-bind- 
Copyright of Annals of Iowa is the property of State of Iowa, by \& through the State Historical Society of Iowa and its content may not be copied or emailed to multiple sites or posted to a listserv without the copyright holder's express written permission. However, users may print, download, or email articles for individual use. 